\title{
Pemetaan Rute Wisata Kampung Biru Arema (KBA) Kota Malang
}

\author{
Tourist Route Mapping of Kampung Biru Arema (KBA) Malang
}

\author{
Fredy Nugroho Setiawan, Rizki Nufiarni, Fariska Pujiyanti \\ Universitas Brawijaya, Malang, Indonesia \\ fredyns@ub.ac.id, nufiarni_rizki@ub.ac.id, fariska puji@ub.ac.id
}

Riwayat Artikel: Dikirim 25 Oktober 2019; Diterima 22 November 2019; Diterbitkan 30 November 2019

\begin{abstract}
Abstrak
Kampung Biru Arema (KBA) adalah salah satu kampung wisata di kota Malang. Kampung tersebut belum memiliki konsep kampung wisata yang baik sehingga hanya mengandalkan aspek estetika mural dan cat berwarna biru di setiap rumah tanpa arah pengembangan rute wisata yang jelas. Oleh karena itu, diperlukan penyusunan rute wisata berdasarkan potensi wisata yang ada di KBA sehingga pengembangan wisata dapat terarah dan berkesinambungan. Untuk melakukan hal tersebut kami menerapkan metode pengembangan wisata model Community Based Tourism (CBT, yaitu: mengikutsertakan anggota masyarakat dalam pengambilan keputusan, memastikan masyarakat lokal menerima manfaat dari kegiatan kepariwisataan, dan memberikan pendidikan kepariwisataan bagi masyarakat lokal. Kegiatan ini menghasilkan sebuah rute wisata di KBA yang disusun dengan mengintegrasikan 5 (lima) area wisata secara berurutan, yaitu Area Wisata Sejarah, Area Wisata Dolanan, Area Wisata Mitigasi Bencana, Area Wisata Arema, dan Area Wisata Basa Walikan. Dalam prosesnya, perumusan rute wisata melibatkan peran serta aktif warga dalam memberikan masukan dan keputusan terkait identifikasi dan pemetaan yang dilakukan. Luaran dari kegiatan ini adalah peta digital berupa rute wisata KBA bagi para wisatawan.
\end{abstract}

Kata kunci: Kampung Biru Arema (KBA), Community Based Tourism (CBT), rute wisata, peta wisata.

\begin{abstract}
Kampung Biru Arema (KBA) is one of the tourism villages in Malang. The village does not have a good tourism village concept so that it only relies on the aesthetic aspects of the murals and blue-painted houses without developing a clear direction of tourist route. Therefore, tourist route mapping which is based on tourism potentials in KBA is needed so that tourism development can be directed and sustainable. To do this we employ the premise of Community Based Tourism (CBT) by ensuring the active involvement of local people in the process of tourism development and management. The activities resulted in a tourist route on the basis of 5 (five) tourism areas, namely Historical Tourisn Area,. "Dolanan" Tourism Area, Disaster Mitigation Tourism Area, Arema Tourism Area, and "Basa Walikean" Tourism Area. In the process of determining the route, it involves the active participation of local people in providing input and decisions related to our identification and mapping of the location. The output of this activity is a digital map of $K B A$ containing informative tourist route for visitors.
\end{abstract}

Keywords: Kampung Biru Arema (KBA), Community Based Tourism (CBT), tourist route, tourist map.

\section{PENDAHULUAN}

Potensi wisata yang saat ini sedang dikembangkan di Kota Malang adalah kampung tematik. Ada 11 (sebelas) Kampung Tematik di Kota Malang yang dipromosikan oleh pemerintah kota, salah satu diantaranya Kampung Biru Arema (selanjutnya disingkat KBA). Kampung Biru Arema terletak di Jalan Embong Brantas, Kelurahan Kidul Dalem, Kecamatan Klojen, Kota Malang. Kampung ini diresmikan oleh Walikota Malang pada tanggal 6 Januari 2018 yang sebelumnya telah bekerjasama dengan PT. Indana Paint sebagai bentuk Corporate Social Responsibility (CSR) dengan sumbangan sebesar Rp 1,5 miliar dalam bentuk cat yang mengubah kampung tersebut menjadi kampung berwarna biru (Sukmasita, 2018, par.2). Berdasarkan hasil wawancara dengan Ketua Kelompok Sadar Wisata (Pokdarwis) KBA, didapatkan informasi bahwa wilayah $\mathrm{KBA}$ 
meliputi dua RW, yaitu RW 4 dan RW 5 Kelurahan Kidul Dalem.

Di KBA ada beberapa elemen yang terlibat dalam pengembangan kampung, yaitu perangkat RW, perangkat RT, Pokdarwis, pengurus Karang Taruna, dan pengurus PKK. Pengembangan KBA belum dikonsep secara jelas meskipun memiliki potensi sebagai kampung wisata. Hasil observasi menunjukkan bahwa infrastruktur yang sudah dikembangkan hanya menyentuh sisi estetis, misalnya mural. Ada banyak mural di KBA yang apabila dilihat sekilas tampak estetis, akan tetapi peletakan mural-mural tersebut terkesan acak dan tidak berdasarkan tema yang terintegrasi dengan potensi area-area wisata dimana mural-mural tersebut berada. Oleh karena itu, pemetaan dan penyusunan rute wisata perlu dilakukan untuk memunculkan identitas wisata kampung tematik khas KBA yang didasarkan pada area-area wisata yang ada di lokasi.

Observasi dan identifikasi lokasi dilakukan beberapa kali. Setelah diperoleh beberapa gambaran tentang KBA, diskusi dengan warga dilakukan dalam forum temu warga pada tanggal 23 Maret 2019. Dari diskusi tersebut, kami mendapatkan beberapa informasi sebagai berikut:

a. Warga belum memiliki konsep yang jelas dalam pengembangan wisata KBA

b. Warga KBA sudah melakukan beberapa pembenahan fisik terutama dalam mengubah kampung kumuh menjadi kampung bersih dengan cara menggandeng beberapa CSR dan swadaya masyarakat

c. Antusiasme sebagian warga dalam membangun kampungnya sangat tinggi, tetapi keterbatasan dana dan pengembangan kampung wisata yang belumg terarah menjadi kendala.

Untuk menanggapi temuan-temuan tersebut, Tim Pengabdian kepada Masyarakat Fakultas Ilmu Budaya Universitas Brawijaya membentuk 5 (lima) kelompok kecil yang masing-masing bertugas mengatasi masalah yang teridentifikasi. Fokus kegiatan tim kami, sebagai salah satu dari lima kelompok kecil yang terbentuk, adalah pembenahan fisik yang berkaitan dengan pengembangan jalur wisata di KBA. Dengan demikian, berdasarkan informasi terhimpun, maka dirumuskan masalah yang perlu untuk dipecahkan, yaitu: bagaimana pemetaan rute wisata yang terdapat di KBA? Hal ini berkaitan dengan bagaimana area-area wisata yang ada nantinya akan dihubungkan dalam satu jalur perjalanan wisata di KBA sehingga setiap area dapat dilalui dan dinikmati wisatawan. Rute ini juga bertujuan untuk mempermudah wisatawan dalam menjelajahi kampung sekaligus mempermudah warga dalam melakukan manajemen sumber daya manusia yang akan mengelola KBA dan mengembangkan wisata berbasis masyarakat.

\section{METODE}

Untuk menjawab masalah yang telah dirumuskan, kerangka pemecahan masalah disusun dengan berlandaskan pada premis Community Based Tourism (CBT) atau pariwisata berbasis masyarakat. Pariwisata berbasis masyarakat adalah model pengembangan pariwisata yang menekankan pada keterlibatan masyarakat lokal, baik secara langsung maupun tidak langsung (Hausler, 2003). Pariwisata berbasis masyarakat merupakan dasar dari sustainable tourism development yang menegaskan bahwa masyarakat bukan lagi menjadi objek pembangunan akan tetapi sebagai penentu pembangunan itu sendiri (Ardika, 2005). Oleh karena itu, agar bisa menjadi subjek pembangunan kampung wisata, warga setempat harus memiliki kemampuan berkomunikasi dan berinteraksi dengan wisatawan yang datang berkunjung dan pengetahuan tentang lingkungan yang menjadi lokasi wisata.

Untuk memaksimalkan potensi wisata dan melibatkan warga masyarakat setempat untuk ikut andil dalam pembangunan pariwisata di KBA, strategi pengembangan pariwisata yang mendorong pemberdayaan 
masyarakat perlu dilakukan. Dalam hal ini, masyarakat mengambil peran sentral dalam pembangunan ekonomi pariwisata setempat. Keterlibatan masyarakat harus dimulai sedini mungkin, mulai dari tahap penentuan potensi destinasi atraksi sumber daya wisata (Damanik dan Weber, 2006). Selain itu, rencana pengembangan wisata yang baik juga harus mengoptimalkan produk barang dan jasa lokal, mengutamakan hak dan tradisi masyarakat di dalam pengelolaan sumber daya alam dan budaya, dan mencermikan kebudayaan dan sejarah setempat dalam pengembangan objek wisata (Murphy, 1998). Oleh karena itu, strategi pengembangan wisata dengan pendekatan Community Based Tourism (CBT) sesuai untuk diterapkan.

Menurut Sunaryo (2013, dalam Rahayu, Dewi, \& Fitriana, 2016), ada 3 (tiga) prinsip pokok dalam strategi perencanaan pembangunan kepariwisatan yang berbasis pada masyarakat (CBT), yaitu: 1) mengikutsertakan anggota masyarakat dalam pengambilan keputusan; 2) adanya kepastian masyarakat lokal menerima manfaat dari kegiatan kepariwisataan; dan 3) pendidikan kepariwisataan bagi masyarakat lokal. Adapun beberapa prinsip CBT yang harus diterapkan, menurut Suansri (2003, dalam Rahayu, Dewi, \& Fitriana, 2016), adalah: 1) mengenali, mendukung, dan mempromosikan kepemilikan masyarakat dalam pariwisata; 2) melibatkan anggota masyarakat dari setiap tahap pengembangan pariwisata dalam berbagai aspeknya; 3) mempromosikan kebanggaan terhadap komunitas bersangkutan; 4) meningkatkan kualitas kehidupan; 5) menjamin keberlanjutan lingkungan; 6) melindungi ciri khas (keunikan) dan budaya masyarakat lokal; 7) mengembangkan pembelajaran lintas budaya; 8) menghormati perbedaan budaya dan martabat manusia; 9) mendistribusikan keuntungan dan manfaat yang diperoleh secara proporsional kepada anggota masyarakat; 10) memberikan kontribusi dengan persentase tertentu dari pendapatan yang diperoleh untuk pengembangan masyarakat; dan 11) menonjolkan keaslian hubungan masyarakat dengan lingkungannya.

Untuk merealisasikan konsep CBT dalam pengembangan wisata di KBA, dilakukan beberapa rangkaian kegiatan sebagai berikut:

a. Observasi dan survei awal bersama perwakilan warga untuk melihat dan mengamati kondisi KBA.

b. Temu warga tahap 1 melalui Focus Group Discussion (FGD), yang bertujuan untuk menjaring informasi tentang area-area yang berpotensi menjadi objek wisata di KBA.

c. Observasi dan eksplorasi lapangan bersama warga untuk menemukan dan menetapkan area-area yang akan dilalui rute wisata.

d. Pemetaan rute wisata tahap 1 di KBA yang direalisasikan dalam bentuk rancangan peta wisata KBA.

e. Temu warga tahap 2 melalui Focus Group Discussion (FGD), yang bertujuan untuk melakukan evaluasi bersama warga dalam bentuk diskusi untuk menunjukkan rancangan hasil pemetaan dan melakukan perbaikan (apabila diperlukan) sesuai kesepakatan.

f. Pemetaan rute wisata tahap 2 di KBA yang direalisasikan dalam bentuk desain peta digital wisata KBA.

g. Soft Launching produk hasil kegiatan, yaitu peta digital wisata KBA.

Agar pelaksanaan kegiatan dapat mencapai sasaran dan memperoleh umpan balik yang membangun, maka evaluasi dilakukan. Evaluasi yang akan dilakukan dalam kegiatan ini bisa dibagi menjadi 2 (dua), yaitu:

a. Evaluasi rutin kegiatan. Dalam tahap ini, kami melakukan evaluasi pada perkembangan pengumpulan data terkait dengan identifikasi titik-titik potensi wisata dan perkembangan pembuatan peta wisata yang juga meliputi kendala yang dihadapi saat membuat peta. 
b. Evaluasi akhir kegiatan. Evaluasi ini merupakan evaluasi secara tertulis dalam upaya penyusunan laporan akhir kegiatan pemetaan rute wisata di KBA.

Adapun indikator capaian pelaksanaan adalah terpetakannya rute wisata $\mathrm{KBA}$ dan terwujudnya sebuah produk peta wisata digital KBA.

\section{HASIL DAN PEMBAHASAN}

\section{A. Tahap Observasi}

Tahap observasi awal kami lakukan pada tanggal 19 Maret 2019. Tahapan ini diperlukan sebagai persiapan pemetaan awal tentang apa yang bisa dilakukan untuk mengembangkan pariwisata di KBA. Pada tahap ini kami menghubungi Pak Irmawan (Ketua Pokdarwis) KBA untuk mendapatkan informasi terkait dengan letak strategis, potensi wisata, dan langkah apa yang sudah dilaksanakan oleh Pokdarwis dalam mengembangkan KBA.

Dari hasil wawancara didapatkan informasi bahwa, saat ini, dalam sehari terdapat $50-100$ wisatawan yang berkunjung ke KBA. Jumlah tersebut diharapkan terus meningkat dengan bantuan dari para akademisi. Informasi lainnya adalah bahwa untuk masuk ke KBA pengunjung dikenai biaya tiket Rp 3.000,00 pada loket yang telah disediakan oleh warga, yaitu jalan kecil menurun di sebelah Jembatan Sungai Brantas. Pengunjung bisa melihat ornamen-ornamen lampion dan mural klub sepakbola Arema pada pintu masuk ini.

Rute awal dalam menjelajahi KBA adalah menuju Ruang Terbuka Hijau (RTH) yang didalamnya terdapat patung singa sebagai simbol Arema, dan untuk menuju patung ini terdapat beberapa lokasi foto yang bisa digunakan oleh pengunjung. Lokasi foto ini merupakan hasil pengabdian masyarakat yang dilakukan oleh Badan Eksekutif Mahasiswa Universitas Brawijaya. Area wisata ini bisa disebut ikonik karena menjadi produk unggulan KBA. Di RTH tersebut juga terdapat jalan tembus yang menghubungkan KBA dengan Kampung
Tridi (kampung wisata tematik yang lokasinya bersebelahan dengan $\mathrm{KBA}$ ). Meskipun akses ini sehari-hari digunakan warga sebagai jalur lalu lintas untuk beraktivitas tanpa harus melewati jalan raya, wisatawan juga menggunakannya. Akses ini juga sudah dihias oleh warga dengan gazebo dan lampion sebagai lokasi foto.

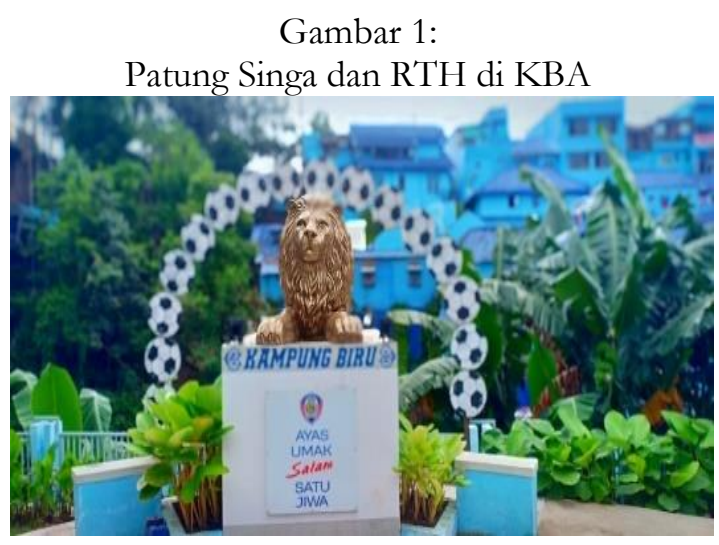

Sumber: Dokumentasi Pribadi

Rute selanjutnya adalah menuju taman organik yang dikelola oleh ibu-ibu PKK KBA. Pada saat kami sedang observasi, ibuibu PKK sedang mengisi polibag dengan kompos untuk ditanami dengan sayuran. Proyeksi ke depan adalah bahwa taman organik ini lebih tertata untuk dijadikan wisata edukasi di KBA.

Destinasi selanjutnya adalah Taman Toga yang berada di RW 6. Di taman ini terdapat beberapa rumah penduduk yang memiliki usaha burung, sehingga seolaholah terlihat seperti taman burung. Pada titik ini juga terdapat beberapa toko kelontong yang menawarkan makanan dan minuman untuk pengunjung.

Selain lokasi-lokasi tersebut, terdapat beberapa hal yang menarik untuk dikunjungi di KBA, yaitu mural-mural tiga dimensi yang digunakan sebagai tempat berfoto. Terdapat juga vertikultur yang dikembangkan oleh penduduk untuk mempercantik lingkungan. Meskipun terdapat beberapa tempat menarik untuk dikunjungi wisatawan, penempatan area-area wisata yang ada masih terkesan sporadis dengan tidak adanya 
petunjuk arah atau jalur khusus bagi wisatawan agar bisa menikmati KBA secara utuh. Hal tersebut menjadi referensi dalam upaya pengembangan KBA dengan melibatkan beberapa elemen masyarakat, yaitu: perangkat kelurahan, perangkat RW, perangkat RT, pengurus KBA (Pokdarwis), pengurus Karang Taruna, dan pengurus PKK. Keterlibatan pihak-pihak tersebut menjadi bagian penting untuk bisa memetakan rute wisata yang terintegrasi, yang dapat memfasilitasi tiap-tiap area wisata KBA.

\section{B. Tahap Pemetaan Awal}

Setelah dilakukan observasi, maka kami menyusun perencanaan untuk mengembangkan rute wisata di KBA. Perencanaan ini kami sampaikan bersama Tim Pengabdian Masyarakat Fakultas Ilmu Budaya Universitas Brawijaya dalam sebuah forum yang dilaksanakan bersama dengan warga KBA pada tanggal 23 Maret 2019. Forum ini dihadiri oleh pengurus Pokdarwis, Karang Taruna dan ibu-ibu PKK. Ide utama yang disampaikan dalam forum ini adalah bagaimana KBA bisa menjadi sebuah lokasi wisata alternatif yang menghadirkan sisi edukasi bagi wisatawan. Selain itu, pengembangan lokasi wisata di KBA juga diharapkan dapat berbasis pada potensi lokal dan meningkatkan ekonomi warga.

Desain pengembangan KBA direncanakan dilakukan dalam 3 (tiga) tahapan, dengan masing-masing tahap akan dilaksanakan selama 1 (satu) tahun. Tahap pertama adalah tahap penataan konsep dan pembekalan yang meliputi penataan konsep KBA dan manajemen pengelolaan, pembekalan ketrampilan bagi SDM, dan penataan KBA sebagai wujud pembangunan fisik. Tahap kedua adalah tahap pengembangan, promosi dan pemasaran yang terdiri dari pengembangan dan pemantapan media promosi dan perintisan kerjasama dan pelaksanaan pembanguan fisik tahap 2. Sedangkan untuk tahap ketiga adalah tahap penguatan yang terdiri dari perintisan kerjasama dengan korporasi dan pelaksanaan pembangunan fisik tahap 3 . Ketiga tahap ini merupakan sebuah rangkaian yang dilakukan untuk mewujudkan sebuah miniatur kota Malang di KBA.

Terkait dengan hasil temu warga tersebut, konsentrasi diarahkan pada pencapaian target tahap pertama di bidang pengembangan aspek fisik KBA. Untuk Pembangunan fisik, rencana tahap pertama yang akan dilakukan dapat dilihat pada bagan berikut.

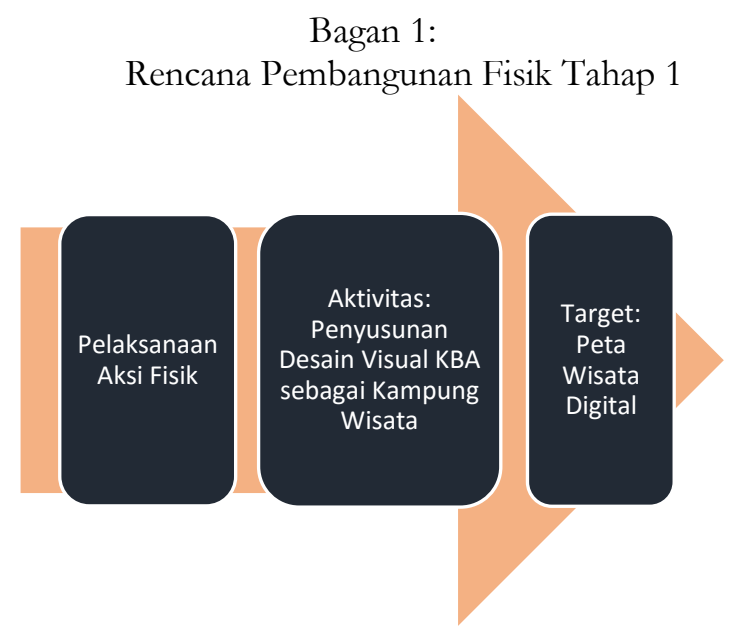

Setelah rencana ini disampaikan kepada warga KBA, maka disepakati bahwa pada tahap pertama ini akan dilakukan penyusunan desain KBA dalam bentuk visual. Desain ini akan diwujudkan dalam bentuk peta wisata berbentuk 2 (dua) dimensi yang menunjukkan rute wisata KBA yang berisi juga informasi tentang area-area wisata yang dapat dikunjungi. Adapun beberapa area wisata yang direncanakan akan dilalui oleh rute tersebut adalah berkaitan dengan pengembangan konsep wisata tematik. Kami melakukan pemetaan lokasi secara langsung di KBA. Pemetaan ini dilakukan untuk menentukan jalur wisata dan area wisata yang dilalui dengan mempertimbangkan kondisi yang ada di lapangan.

Setelah dilakukan survei lokasi, maka direncanakan sebuah rute yang akan menghubungkan 5 (lima) area wisata secara 
berurutan, yaitu Area Wisata Sejarah, Area Wisata Dolanan, Area Wisata Mitigasi Bencana, Area Wisata Arema, dan Area Wisata Basa Walikan. Berikut adalah peta rute wisata dan lokasi masing-masing area wisata yang dimaksud.

Gambar 2:

Rute dan Area Wisata KBA Versi Awal

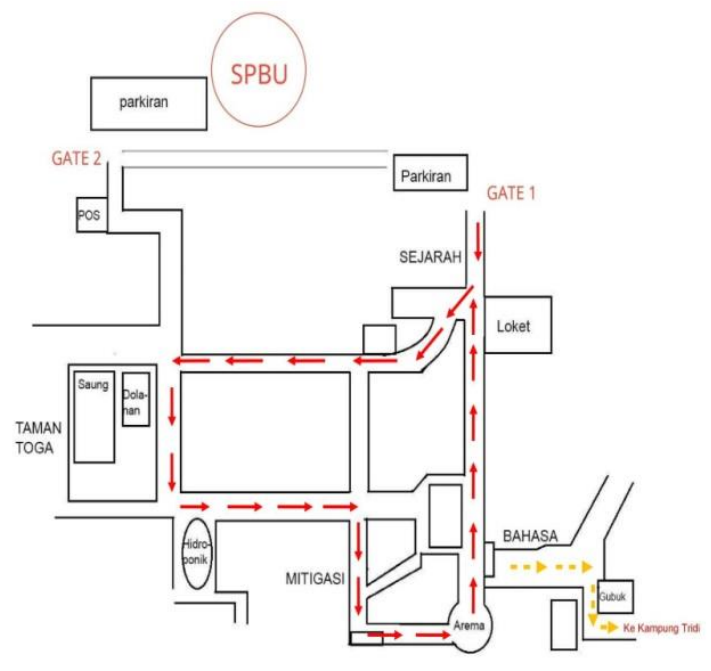

Pada gambar diatas terlihat bahwa Pintu Masuk dan Keluar diletakkan pada posisi yang sama yaitu di Gate 1, dimana lokasi loket masuk sekarang ini berada. Dengan jalur ini, maka area wisata yang akan dilalui wisatawan secara berurutan adalah Area Wisata Sejarah di dekat Gate 1 dan loket masuk, Area Wisata Dolanan di sebelah Taman Toga, Area Wisata Mitigasi Bencana di dinding dekat lokasi hidroponik, Area Wisata Arema yang tetap di lokasi yang sudah ada (yang sudah dibangun oleh pemerintah kota), dan Area Wisata Basa Walikan di jalan yang biasa dilalui warga untuk menuju Kampung Tridi. Setelah melalui Area Basa Walikan, wisatawan dapat langsung menuju Kampung Tridi dengan melalui jalan di bawah jembatan Buk Gluduk. Jalur wisata dan area yang sudah dipetakan ini kemudian didiskusikan bersama dengan pengurus Pokdarwis KBA untuk mendapatkan masukan.

\section{Tahap Pemetaan Akhir}

Menurut Tampubolon (1977), salah satu bentuk keterlibatan warga masyarakat dalam pengembangan pariwisata berbasis masyarakat adalah memberikan sumbangan berupa kebijaksanaan dan pengetahuan dalam rencana pembangunan. Dengan demikian, saran dan masukan yang sifatnya konstruktif dari elemen warga masyarakat setempat berperan krusial untuk merealisasikan semangat CBT (Community Based Tourism) sekaligus membangun sebuah desa wisata yang secara optimal mampu memberdayakan sumberdaya manusia di desa tersebut. Prinsip ini diterapkan dalam langkah lanjutan pemetaan rute wisata KBA. Realisasinya adalah dengan melakukan komunikasi dan diskusi dengan pengurus $\mathrm{KBA}$ tentang rancangan peta wisata $\mathrm{KBA}$ yang telah kami susun dan sepakati dalam rapat evaluasi rutin kegiatan.

Hasil kesepakatan awal kami yang memutuskan bahwa jalur wisata KBA dimulai dari Gate 1, yaitu gapura masuk KBA di sebelah jembatan Buk Gluduk, dilanjutkan dengan melalui lima (5) titik wisata secara berurutan, yaitu: Area Wisata Sejarah, Area Wisata Dolanan, Area Wisata Mitigasi Bencana, Area Wisata Arema, dan Area Wisata Basa Walikan, dan diakhiri melalui jalur yang sama dengan jalur masuk kampung, mengalami penyesuaian berdasarkan saran dan masukan dari pengurus Pokdarwis KBA. Penyesuaian tersebut diperlukan berdasarkan rencana warga yang ingin menjadikan Gate 2 (pintu masuk KBA di sebelah SPBU Pertamina di Jl. Trunojoyo I, Kidul Dalem) menjadi pintu masuk utama ke KBA. Rencana tersebut didasarkan pada faktor akses masuk kendaraan untuk parkir dan faktor demografis KBA yang menurut warga lebih sesuai. Keputusan untuk melakukan penyesuaian diperoleh dalam sebuah forum rapat koordinasi. Hasil dari penyesuian rute wisata tersebut adalah perubahan rancangan peta wisata KBA sebagai berikut. 
Gambar 3:

Rute Wisata KBA Versi Revisi Warga

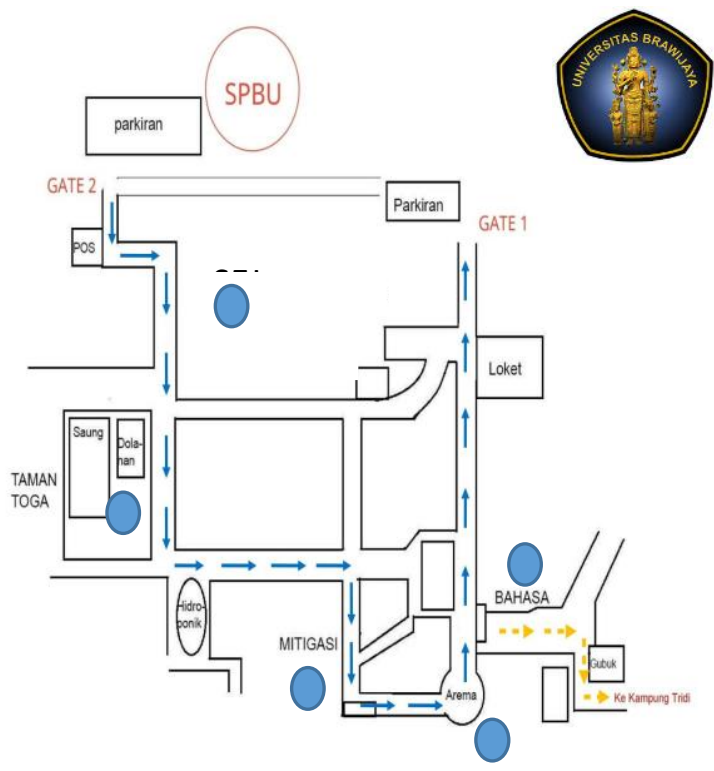

Sebagaimana dapat dilihat di Gambar 3, jalur masuk ke KBA adalah dari Gate 2 dan jalur keluar adalah dari Gate 1. Hal ini berbeda dengan rancangan awal dimana jalur masuk dan keluar KBA berada di satu pintu yang sama, yaitu Gate 1. Konsekuensi dari perubahan rute wisata KBA tersebut adalah perubahan lokasi salah satu area wisata, yaitu Area Wisata Sejarah. Sebelumnya area tersebut berada tepat setelah pintu masuk di Gate 1; setelah mengalami revisi, area tersebut dipindahkan ke lokasi setelah pos jaga yang berada tepat setelah pintu masuk Gate 2. Adapun empat area wisata lain tidak mengalami perubahan karena masih mengikuti alur yang sama dengan rencana awal dari kami.

Perubahan rute wisata dan salah satu lokasi area wisata KBA dengan mempertimbangkan masukan dari pengelola KBA merupakan wujud pemberdayaan komunitas lokal untuk berperan aktif dalam pembangunan desa. Mengingat dalam pengembangan kepariwisataan, aspek pemberdayaan komunitas lokal telah menjadi salah satu kesepakatan dan komitmen yang harus diwujudkan. Hal tersebut sejalan dengan salah satu prinsip kepariwisataan yang terkandung dalam Undang-Undang No.10
Tahun 2009 tentang kepariwisataan yang menyatakan bahwa masyarakat berhak berperan dalam proses pembangunan kepariwisataan dan berkewajiban menjaga dan melestarikan daya tarik wisata; serta membantu terciptanya suasana aman, tertib, bersih, berperilaku santun, dan menjaga kelestarian lingkungan destinasi pariwisata (Purnamasari, 2011). Melalui penyesuaian antara rencana kami dan gagasan warga $\mathrm{KBA}$, diharapkan masyarakat dapat merasa terlibat dan nyaman dalam mengelola lingkungan kampung mereka sehingga dapat menjadi daerah tujuan wisata yang menarik bagi para wisatawan.

Setelah draft akhir peta wisata KBA berhasil disusun, diseminasi dilakukan kepada masyarakat setempat dalam sebuah pertemuan dengan warga pada tanggal 7 Agustus 2019 jam 19.00. Forum tersebut dihadiri oleh perwakilan dari pengurus RW, RT, Pokdarwis, PKK, Karang Taruna, dan warga dari pihak KBA dan kami dari pihak Fakultas Ilmu Budaya Universitas Brawijaya. Diseminasi dilakukan dalam bentuk presentasi hasil kesepakatan antara kami dan perwakilan elemen masyarakat KBA dan tanya jawab seputar eksekusi rancangan kesepakatan tersebut. Presentasi berupa sosialisasi rancangan rute wisata dan penjelasan mengenai area-area wisata yang akan dilalui oleh rute tersebut. Diseminasi tersebut bermuara pada implementasi gagasan Traditional Tourism Village, yaitu pengembangan pariwisata yang menonjolkan budaya dan adat istiadat KBA dan gaya hidup masyarakatnya yang dikemas dalam lingkungan yang menarik, yaitu rumah-rumah dan bangunan-bangunan di sekitarnya yang tidak sekadar dicat dengan warna biru tetapi jugamenghadirkan wisata khas "Kampung Ledok" di Malang.

Rancangan rute dibuat untuk memberikan gambaran konkret sekaligus panduan bagi warga KBA yang nanti secara gotong-royong akan mengecat dan memperindah jalur dan area wisata. Artinya, tugas untuk menggarap jalur dan area wisata di lapangan, termasuk pengurusan 
pendanaannya, dilakukan sendiri oleh warga $\mathrm{KBA}$, sedangkan kami membatasi diri pada fungsi pendampingan. Hal tersebut dilakukan mengingat dalam konteks pariwisata berbasis masyarakat, posisi masyarakat bukan lagi menjadi objek pembangunan akan tetapi sebagai penentu pembangunan itu sendiri (Ardika, 2005). Oleh karena itu, mereka harus menjadi subjek yang berdikari.

Setelah kegiatan temu warga dan diseminasi selesai dan warga bersepakat untuk mendukung eksekusi program, kami melanjutkan kegiatan dengan melakukan koordinasi dengan arsitek professional untuk keperluan survei dan pemetaan akhir dilapangan.Koordinasi dan komunikasi intensif antara kami dan arsitek telah dilakukan sejak tanggal 3 September 2019. Persiapan intensif diperlukan untuk menyamakan persepsi dan target luaran yang akan dihasilkan setelah pemetaan akhir di lapangan. Pada akhirnya diputuskan bahwa produk yang dihasilkan adalah sebuah peta digital yang berisi informasi rute dan area-area wisata di KBA.

Produk luaran kegiatan berbentuk digital karena beberapa pertimbangan. Pertimbangan pertama adalah peta digital berbentuk softfile yang dapat digunakan secara praktis dan fleksibel untuk berbagai macam keperluan. Apabila diperlukan dalam bentuk fisik, misalnya dalam bentuk papan informasi, poster, baliho, dan lainlain untuk ditampilkan di lokasi wisata, peta digital tersebut dapat dicetak dan dikondisikan sedemikian rupa sesuai dengan penempatannya. Apabila diperlukan untuk dapat diakses bebas oleh khalayak yang berminat mengunjungi KBA, peta digital dapat ditampilan di laman web dan media sosial KBA. Pertimbangan kedua adalah format peta digital merupakan target yang feasible untuk dapat dicapai dalam kurun waktu yang relatif singkat. Ini terkait dengan linimasa kegiatan kami yang terbatas dan faktor urgensi kemunculan produk yang bisa segera dilihat oleh warga KBA sehingga mereka lebih bersemangat untuk menyukseskan sustainable tourism development. Pertimbangan ketiga adalah peta digital merupakan media informasi yang lebih menarik, terutama bagi kaum milenial yang banyak terpapar teknologi digital.

Kegiatan pemetaan akhir wisata KBA dilaksanakan pada tanggal 7 September 2019 jam 09.00. Proses pemetaan dilakukan berdasarkan rancangan peta wisata dan dengan melibatkan arsitek yang bertugas mendesain rancang bangun rute wisata di KBA dalam bentuk karya arsitektur digital. Arsitektur digital adalah istilah singkat untuk menggambarkan pemakaian teknologi komunikasi dan informasi dalam proses perencanaan dan perancangan arsitektur secara total (Satwiko, 2009). Dalam hal ini, kami memanfaatkan teknologi Google Map dan Google Earth untuk membantu. Hasilnya adalah sebagai berikut:

Gambar 4:

Rute Wisata KBA Versi Akhir

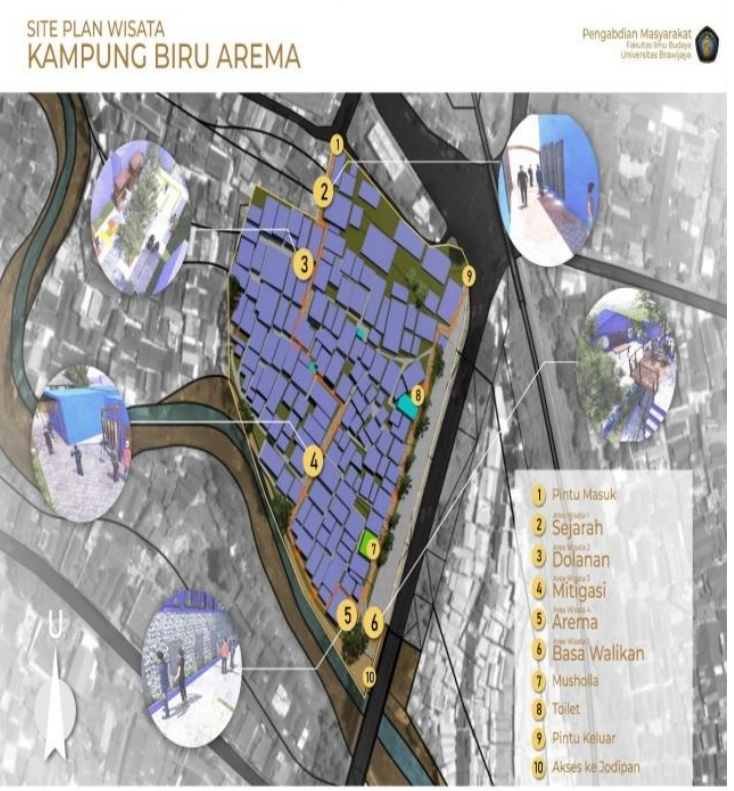

\section{KESIMPULAN}

Kampung Biru Arema (KBA) adalah salah satu kampung wisata tematik yang digagas oleh Pemerintah Kota Malang untuk meningkatkan kesejahteraan warga masyarakat berbasis Community Based Tourism (CBT). Meskipun pemukiman warga secara fisik sudah dikemas dengan cukup menarik, 
KBA belum memiliki arah pembangunan daerah wisata yang menerapkan prinsip pengembangan pariwisata berkelanjutan karena potensi yang ada di kampung tersebut belum dimaksimalkan. Oleh karena itu, kegiatan pemetaan rute wisata di KBA ini menawarkan sebuah gagasan kampung wisata yang berbasis Traditional Tourism Village dengan memunculkan kekhasan budaya, tradisi, dan kearifan lokal Malang, khususnya Kampung Ledok, yang teraktualisasi melalui jalur penjelajahan lokasi-lokasi wisata di wilayah KBA. Pemetaan menghasilkan sebuah rute wisata yang mengintegrasikan 5 (lima) area wisata khas KBA menunjukkan bahwa potensi KBA sebagai salah satu destinasi wisata tematik dapat dikembangkan secara lebih terarah. Pada tahap pertama ini, luaran berupa peta wisata digital KBA diharapkan dapat menjadi titik tolak pengembangan kampung yang berkelanjutan agar dapat lebih dikenal oleh wisatawan, layaknya Kampung Warna Warni dan Kampung Tridi yang berada di Kelurahan yang sama, sehingga bermuara pada peningkatan kesejahteraan warga dan kesadaran akan pentingnya menjaga dan mengelola lingkungan sekitar.

Kami berharap bahwa hasil kegiatan ini dapat menjadi masukan bagi pemerintah kota, khususnya Dinas Pariwisata kota Malang, para stakeholders dan CSR untuk memberikan dukungan yang tidak hanya bersifat material tetapi juga gagasan agar wacana pengembangan kampung tematik di wilayah Malang Raya lebih terarah dan tepat guna.

\section{UCAPAN TERIMA KASIH}

Kami mengucapkan terima kasih kepada Tim Pengabdian kepada Masyarakat Fakultas Ilmu Budaya Universitas Brawijaya di KBA yang telah menggagas dan melaksanakan kegiatan pengembangan wisata KBA secara bersama-sama. Tim tersebut terdiri dari beberapa tim kecil, yaitu: Tim Curah Gagasan, Tim Pelatihan Bahasa, Tim Jurnalistik, Tim Fisik 1 dan Tim Fisik 2.
Tulisan ini merupakan bagian dari laporan Pengabdian kepada Masyarakat Tim Fisik 2, tim kami, yang tidak terpublikasikan. Oleh karena itu, beberapa data yang menjadi referensi dalam tulisan ini diperoleh secara bersama-sama sebagai satu Tim Kelompok Pengabdian kepada Masyarakat Fakultas Ilmu Budaya Universitas Brawijaya di KBA. Meskipun demikian, tulisan ini merupakan tulisan otentik kami yang berdasarkan pada kegiatan lapangan Tim Fisik 2 di KBA.

Kami juga mengucapkan terima kasih kepada warga dan jajaran struktural KBA Kampung Ledok, Kidul Dalem, Kota Malang, yang telah berkenan memfasilitasi kegiatan kami dan proaktif dalam upaya pengembangan wisata kampung tematik yang berkelanjutan.

\section{DAFTAR PUSTAKA}

Ardika, I Wayan. (2004). Pariwisata Bali: Membangun Pariwisata-Budaya dan Mengendalikan Budaya Pariwisata. Dalam "Bali Menuju Jagadhita: Aneka Perspektif'. Denpasar: Pustaka Bali Post, hlm 20-33.

Damanik, Janianton dan Weber, Helmut F. (2006). Perencanaan Ekowisata: dari Teori ke Aplikasi. Yogyakarta: Penerbit Andi.

Hausler, Nicole dan Strasdas, Wolfgang. (2003). Training Manual For Community Based Tourism. InWEnt, Zschoutau.

Murphy, Peter. E. (1998). Tourism : A Community Approach. London : Methven.

Purnamasari, Andi Maya. (2011). Pengembangan Masyarakat untuk Pariwisata di Kampung Wisata Toddabojo Provinsi Sulawesi Selatan. Dalam "Jurnal Perencanaan Wilayah dan Kota", Vol. 22 No. 1, April 2011, hlm. $49-64$.

Rahayu, Sugi; Dewi, Utami; dan Fitriana, Kurnia Nur. (2016). Pengembangan Community Based Tourism sebagai Strategi Pemberdayaan ekonomi Masyarakat di Kabupaten Kulon Progo, Daerah Istimewa Yogyakarta. Dalam "Jurnal Penelitian Humaniora", Vol. 21, No. 1, April 2016, hlm. 1-13. 
Sukmasita, Hezza. (2018). Resmi Dibuka, Kampung Biru Siap Sajikan Segala Hal tentang Arema. Diakses tanggal 26 maret 2019 dari laman https://www.malangtimes.com/baca/2 4736/20180206/141648/resmi-dibukakampung-biru-siap-sajikan-segala-haltentang-arema

Tampubolon. (1977). Perencanaan Kesejabteraan Sosial. Yogyakarta: Kelompok Penelitian Sosial dan Politik. 